\title{
HISTOPATHOLOGICAL EXAMINATION OF A BILATERAL SYMMETRICAL CYST OF THE RETINA*
}

\author{
BY \\ J. FRANÇOIS AND M. RABAEY \\ From the Ophthalmological Clinic, University of Ghent, Belgium
}

SOME time ago one of us published a clinical study of retinal cysts in general and of bilateral symmetrical cysts (cysts of the ora serrata, according to Weve, 1935) in particular. The latter present several characteristics:

(1) They are situated at the extreme periphery and generally at the inferotemporal part of the retina, which elsewhere appears to be perfectly normal and healthy.

(2) They are nearly always bilateral and symmetrical.

(3) They are usually solitary and form a translucent, prominent, globular mass, situated between the equator and the ora serrata. Their wall is regular and smooth, their form round or oval, their contents transparent and their contours well defined. The retinal vessels, which seem to be intact, arise at their level and appear a little more sinuous and darker than in the rest of the retina.

(4) They have the reputation of provoking a retinal detachment by rupture of the cyst (Shapland, 1948) or by desinsertion of the membrane (Weve, 1935), and have nearly always been observed after this complication (Weve, 1935; Ridley, 1936; Custodis, 1936; Bartels, 1933; Kurz, 1944; Jancke, 1935; Duke-Elder, 1949; Rubino, 1946; Schaub, 1940; Stallard, 1946; Leffertstra, 1950).

Up to the present only four clinical observations of cysts of the ora serrata without detachment are known. Observations have been published by Weve (1935, Case 5), Bonnet and Bussy (1935), Kornzweig (1940), and François and Lambrechts (1952). We have the impression that if these cysts were more systematically sought, they would be more often found. It must not be forgotten that their situation at the extreme periphery and the fact that they do not cause any subjective trouble make their discovery more difficult.

We have recently had the opportunity of observing a second case, and have been able to study it histopathologically.

\section{Case Report}

A married woman, aged 72, presented herself for consultation on September 16, 1952 , complaining of hemicranial pains on the right side, and diplopia with progressive exopht'almos of the right eye. The symptoms had started 6 months before.

* Received for publication May 9, 1953. 
Examination, Right Eye:

(i) Direct and irreducible exophthalmia of $8 \mathrm{~mm}$.; the exophthalmometer showed $24 \mathrm{~mm}$. right, and $16 \mathrm{~mm}$. left.

(ii) Dilatation and pronounced tortuosity of the episcleral veins.

(iii) Paralysis of the superior rectus, paresis of the inferior rectus, internal rectus, external rectus, and inferior oblique, with ptosis palpebrae superioris.

(iv) Diminution of corneal sensitivity.

(v) Shallow anterior chamber with narrowing of otherwise normal irido-corneal angle.

(vi) Diffuse senile atrophy of the retina, involving especially periphery and accompanied by irregular pigmentation.

(vii) Retinal cyst situated in the infero-temporal area of the ora serrata, extending from 6.30 to 10 o'clock, 16 dioptres prominent and presenting all the characteristics described above. It was a single, translucent, globular mass, with a regular, smooth surface, elongated shape, transparent contents, and well-defined contours.

(viii) Visual acuity 5,10 ; visual field presented a slight supero-nasal depression corresponding to the retinal cyst.

(ix) Ocular tension raised to $28 \mathrm{~mm}$. $\mathrm{Hg}$. This interesting point can be explained in the following way: the orbital tumour produced a disturbance of the return circulation, causing dilatation and hypertension of the episcleral veins. The hypertension prevented the normal drainage of the aqueous humour through Schlemm's canal and the efferent venous system.

Left Eye.-We saw no orbital sign or abnormality of the anterior segment, but we found the same senile atrophy of the retina and a retinal cyst near the ora serrata, identical with that in the right eye. The visual acuity was $10 / 10$, the visual field complete, and the ocular tension $18 \mathrm{~mm}$. $\mathrm{Hg}$.

History.-The patient had undergone a hysterectomy at the age of 42 . Her husband and her son had both died of pulmonary tuberculosis.

$X$-Ray Examinations.-The right orbit showed an irregularity of the external extremity of the sphenoidal fissure and a diminished distinctness of the inferior border of the optic foramen. The skull showed a calcification immediately to the right of the medial line in the fronto-parietal region. A left occipital exostosis was also seen.

Internal, Neurological, and Oto-rhinological Examinations.-Negative.

\section{Laboratory Examinations:}

Sedimentation Rate: $7 \mathrm{~mm}$. after 1 hour, $18 \mathrm{~mm}$. after 2 hours (Westergren).

Blood count: haemoglobin 80 per cent.; red cells $4,000,000$; white cells 4,600 ; lymphocytes 21 ; eosinophils 3 ; basophils 0 ; monocytes 2 ; neutrophils 73 .

Urine: no sugar, no albumin.

Hyperglycaemia test :

\begin{tabular}{|c|c|c|c|}
\hline Time & & $\begin{array}{c}\text { Glycaemia } \\
\text { (g. per thou.) }\end{array}$ & Glucosuria \\
\hline $\begin{array}{l}\text { Fasting } . . \\
\text { After } 45 \text { minutes } \\
\text { After } 90 \text { minutes }\end{array}$ & $\begin{array}{l}\cdots \\
\cdots \\
\cdots\end{array}$ & $\begin{array}{l}1 \cdot 11 \\
1 \cdot 81 \\
2 \cdot 0\end{array}$ & $\begin{array}{l}\text { Negative } \\
\text { Negative } \\
\text { Nega tive }\end{array}$ \\
\hline
\end{tabular}

Bordet-Wassermann and Kahn tests negative, Meinicke positive.

Cerebro-spinal fluid: Tension and Queckenstedt test normal; bacteriological examination negative.

Electro-Encephalographic Examination.-Basal rhythm very irregular. Positive reaction to light and sound stimulation, and tendency to hypersynchronia on closure of the lids. Fronto-occipital, differentiation little pronounced. Right cortex more active than the left, and most sensitive for a rhythm of $7 \mathrm{sec}$. After hyperventilation there was from time to time a paroxysmal dysrhythmia.

Electro-Retinography.-Positive right and left, but no cortical response to light stimulation when left eye closed; it seemed as if the retro-ocular tumour prevented the passage of the impulse from the retina. 
Histopathological Examination of Retinal Cyst

After exenteration of the right orbit, the ocular globe was fixed in formol 10 per cent., and then divided into two following the frontal plane at the level of the equator (Fig. 1).

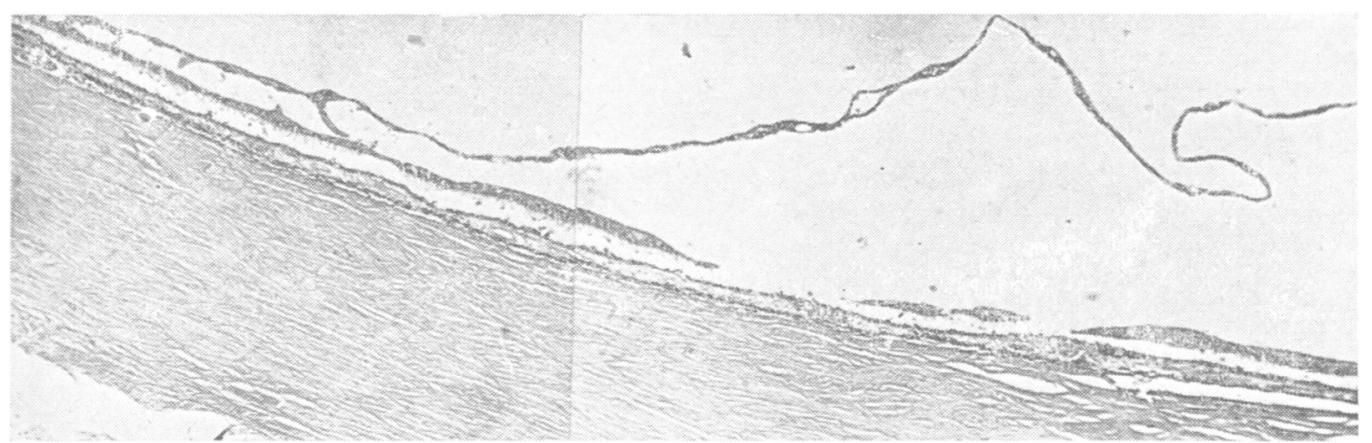

FIG. 1.-Section of large cyst in peripheral retina. Note hole formations in outer wall.

After inclusion in paraffin, serial sections were made; these also followed the $\stackrel{9}{?}$ frontal plane, starting from back to front for the anterior segment.

The posterior segment, sectioned in the usual way following the horizontal $\frac{?}{0}$ plane, showed no other abnormalities except those expected in physiological $\stackrel{\oplus}{\square}$ senile atrophy. We found no histological alteration of the vessels of the reting $\vec{c}$ or choroid.

As for the anterior part, as the ora serrata was approached, we observed, on the outside of the retinal cyst, an important microcystic degeneration which occupied the whole circumference of the retina (Fig. 2). We saw at once that the cyst could not be considered as a true tumour formation with a wall and heterogeneous

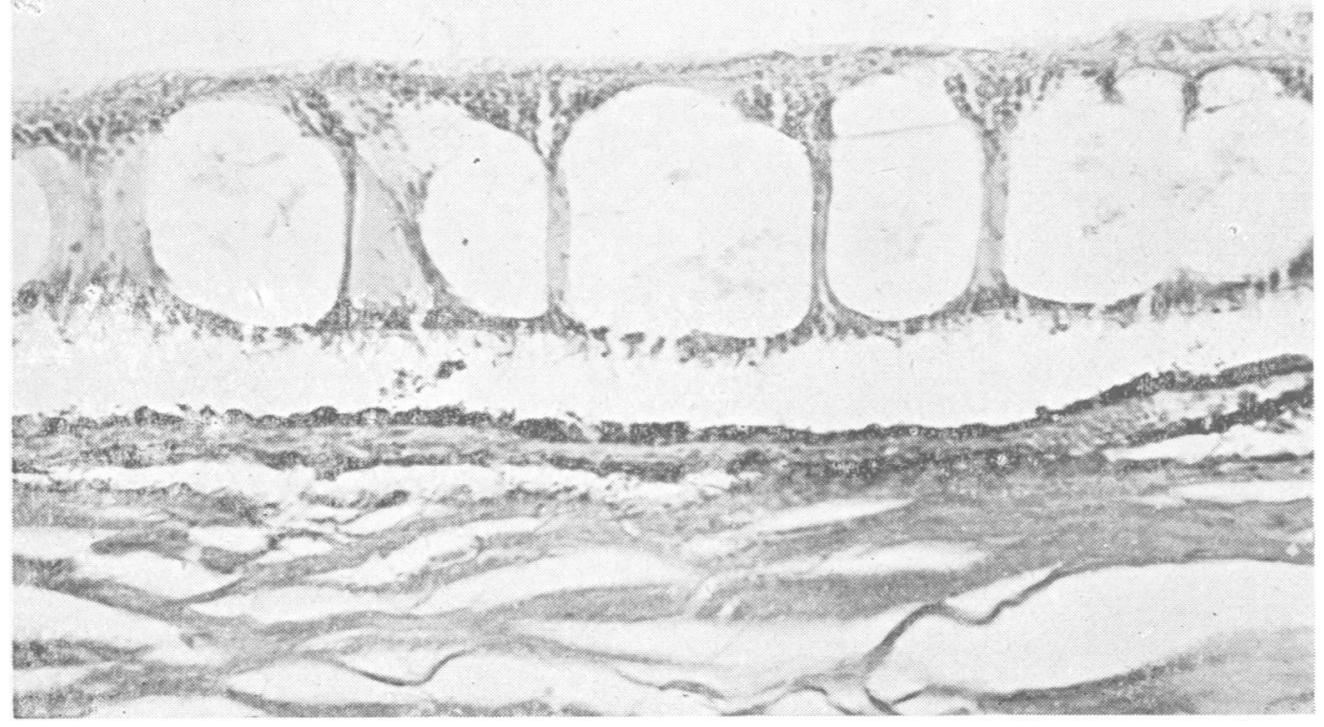

Fig. 2.-Extensive cystoid degeneration near ora serrata. $\times 125$. 
structure. It appeared, on the contrary, as a cavity formed in the retina by the fusion of smaller cysts dependent on the peripheral cystoid degeneration. All these formations contained a little chromotropic material.

The external wall of the cystic cavity was constituted by the degenerated remains of the rods and cones and the external granular layer, with here and there some residuum from the external plexiform layer (Fig. 3).

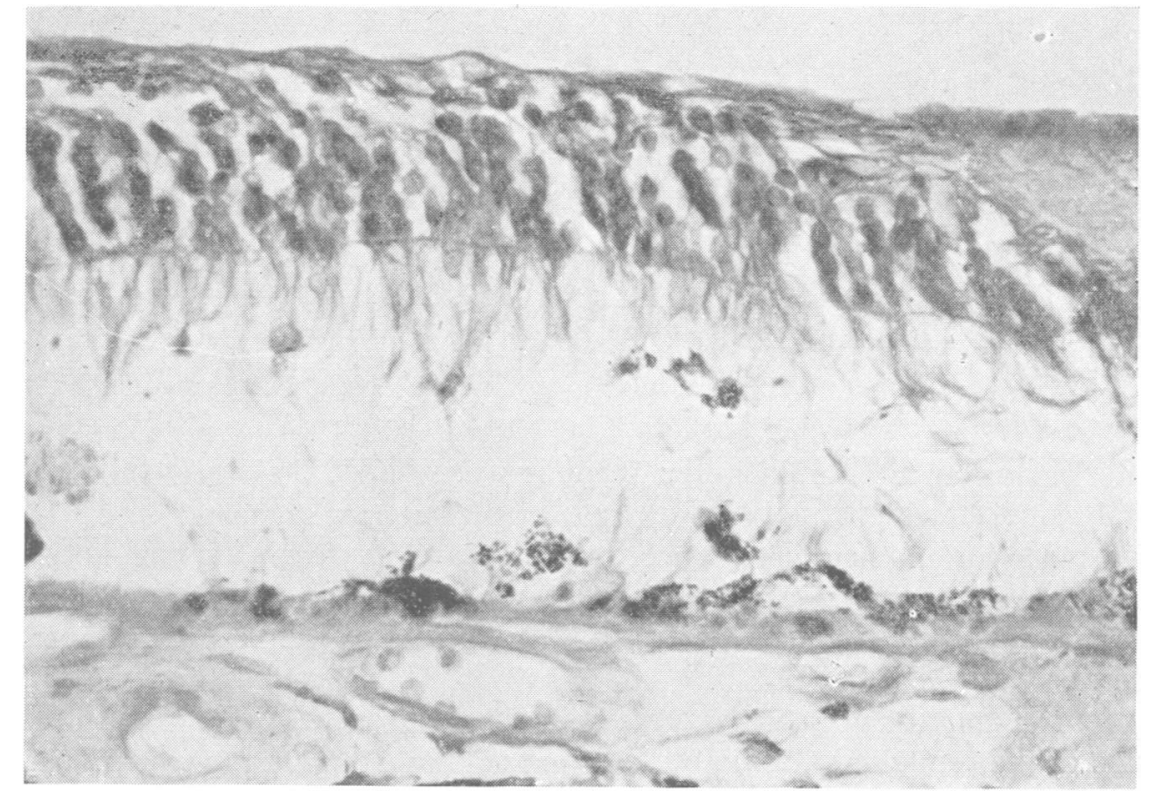

Fig. 3.-Outer wall of large cyst. $\times 500$.

At several places this wall was broken so that the cavity was in direct contact with the pigment epithelium (Fig. 4).

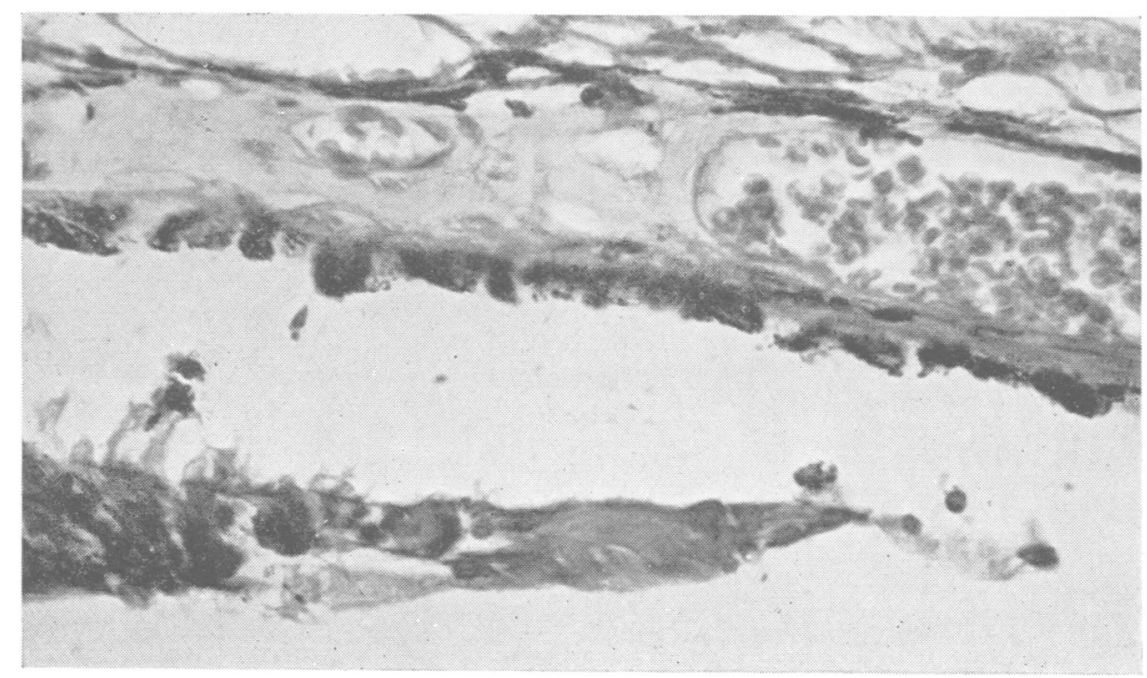

FIG. 4. - Hole formation in outer wall of large cyst. $\times 500$. 
The pigment epithelium cells were normal at certain places, destroyed at others. Elsewhere proliferation and migration of these cells were seen. The choroid appeared completely normal.

The internal wall of the cyst was prominent towards the interior of the globe. It was, at least in the preparation, irregularly folded. It was made up of glial tissue and connective fibres, in which several vessels were found (Fig. 5). These vessels, whether arteries or veins, presented a normal structure.

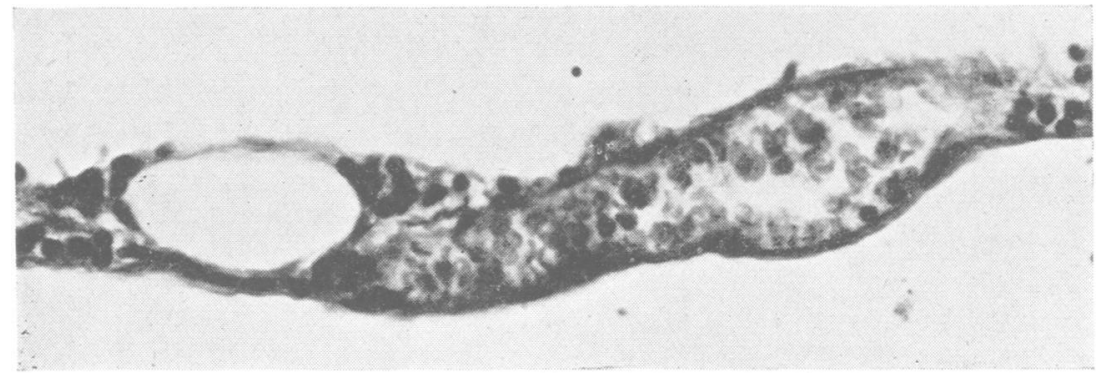

FIG. 5.-Inner wall of cyst with blood-vessel. $\times 500$.

On the border of the large cyst, pillars of supporting tissue were observed between the external and internal walls (Fig. 6).

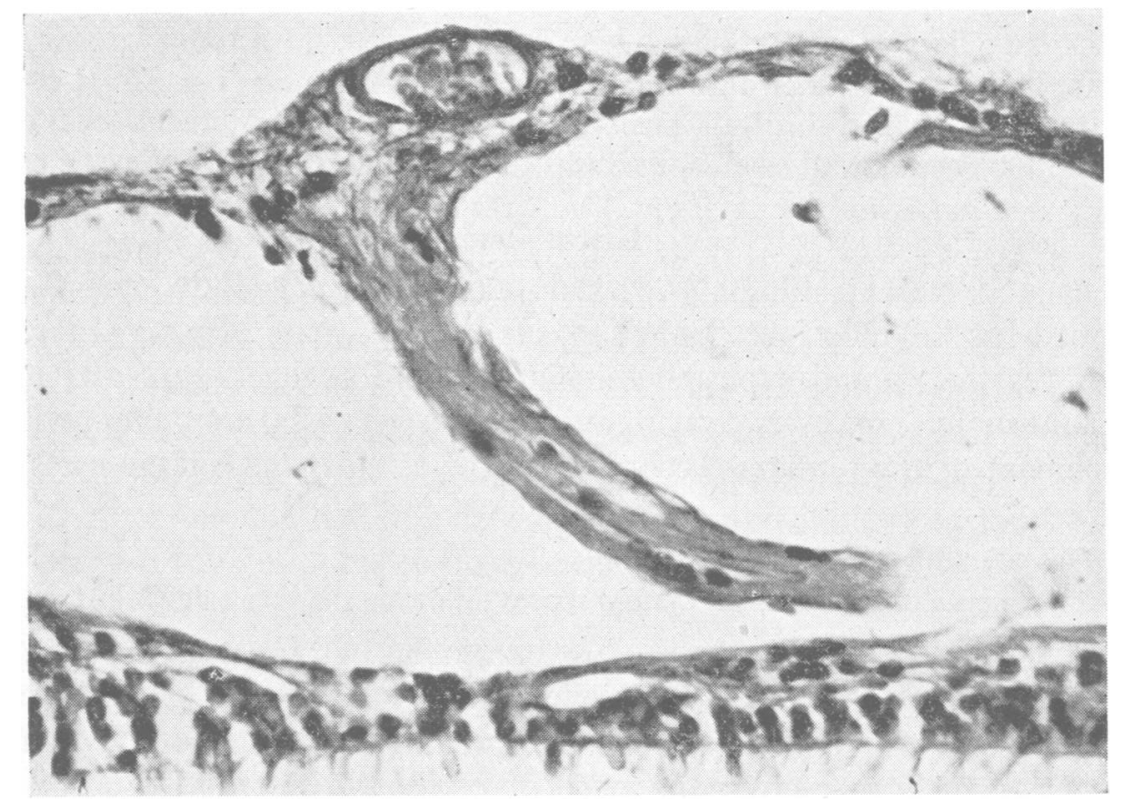

FIG. 6.-Pillars of supporting tissue between cystoid spaces in area of cystoid degeneration. $\times 500$.

These pillars became fewer and finally disappeared, so that there was a progressive, almost imperceptible transition between the microcystoid formations 
and the large cavity (Fig. 7).

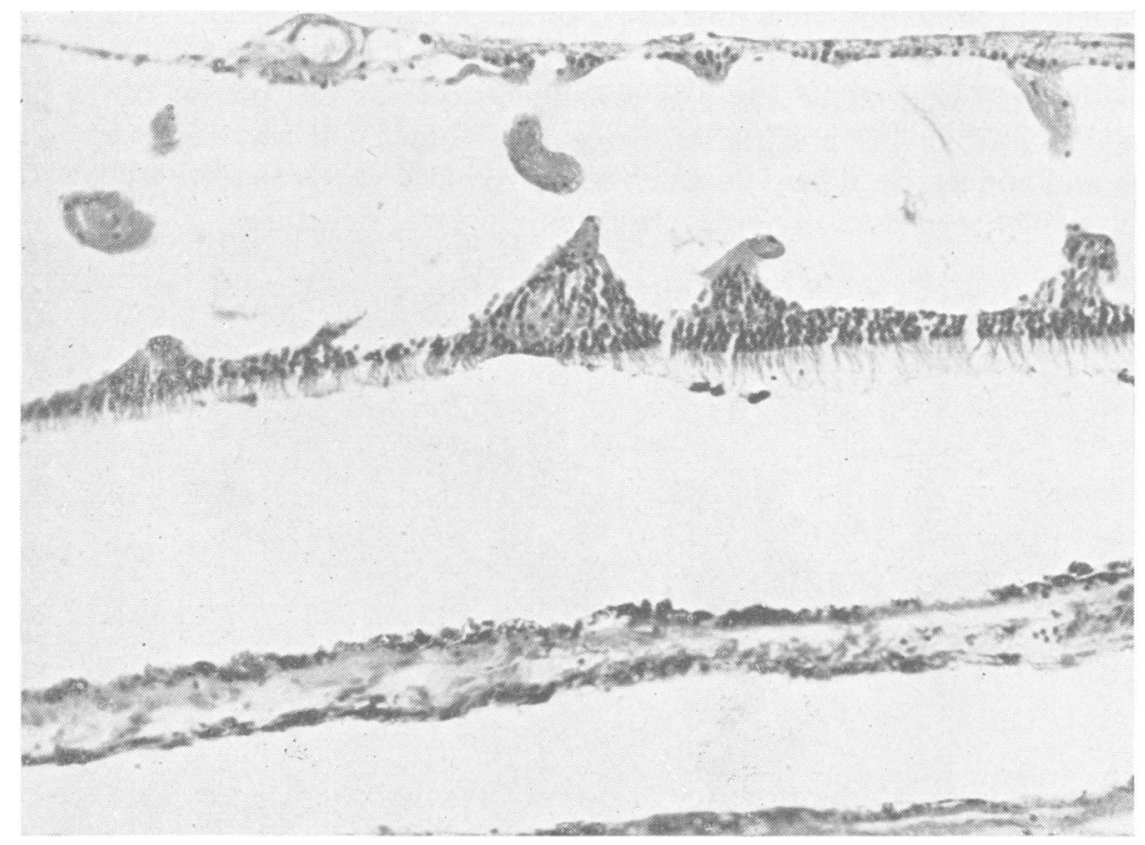

Fig. 7.-Transition between area of cystoid degeneration and large cyst. $\times 125$.

Once the pillars of supporting tissue had disappeared, it was not surprising that the internal wall prot:uded into the vitreous by the pressure of the fluid coming from the choroid, and this took place the more easily because, at the level of the holes in the external wall, the choroid was in direct contact with the cystic cavity.

\section{Discussion}

Teng and Katzin (1953) have made an anatomical study of 170 eyes, obtained for the most part from subjects over 30 years of age. In 157 of these eyes they found a peripheral microcystoid degeneration, and in ten cases unusually large cysts, varying in size from 0.3 to $8.0 \times 4.0 \mathrm{~mm}$., without detachment of the retina. According to the authors these large cysts may be due to:

(i) Dilatation of single cystoid spaces.

(ii) Confluence of several small cystoid spaces following the break-down of the pillars of supporting tissue.

(iii) These two processes combined.

In our case the histopathological examination gave evidence that the large cyst was formed by confluence of peripheral microcysts. This fact seems to us very important for the following reasons:

(1) Many authors (Weve, 1935; Fuchs, 1937; Elwyn, 1946; Shapland, 1948; Charamis, 1947; Kornzweig, 1940) attribute a dysgenetic and congenital origin to cysts near the ora; they regard them either as embryological malformations or as the sequelae of a peripheral intraretinal haemorrhage, occurring before birth 
or after obstetrical trauma. This explanation is not surprising, if the fact be taken into consideration that most of the retinal cysts near the ora which have been observed hitherto have been found in young subjects of from 10 to 30 years old, emmetropes or hypermetropes. But our two patients were aged 54 and 72 years respectively.

(2) In our first study we separated clearly the microcystoid degeneration of the retina and the large bilateral symmetrical cysts. The histopathological examination of our second case shows that this opinion is erroneous, and that in fact a peripheral cystic formation, presenting all the clinical characteristics of a cyst near the ora (Weve, 1935), may depend only on an advanced cystoid degeneration.

In three cases reported by Teng and Katzin (1953) there were retinal holes. In one case, perforation had occurred through both walls of a cystoid space, and in the other two only the external wall was perforated. Our case also showed several holes in the external wall, but no interruption of the internal wall.

The fact that no detachment of the retina occurred in these cases shows that the perforation of the external as well as the internal wall, or, which amounts to the same thing, the desinsertion of the retina, constitutes a necessary condition of its occurrence.

Nothing is known of the mechanism of peripheral cystoid degeneration of the retina and of the consequent cysts near the ora. The cystoid degeneration, which first involves the inter-granular layer, represents a purely degenerative or atrophic process, due to a disintegration or a rarefaction of the tissues, and vacuolar degeneration of the cells. It is most often observed in myopic or senile retinae; according to Teng and Katzin (1953), it is nearly always seen after the 40 th year, but these authors have also encountered it among young subjects (one child of $5 \frac{1}{2}$ months, and two patients aged 20 to 30 years).

Metabolic, vascular, infective, toxic, and traumatic causes have all been suggested, including a shrinkage of cells (Kuhnt, 1881; Landsberg, 1877; Oguchi, 1912), accommodation (Teng and Katzin, 1953), motility and lymph stasis (Ochi, 1927), poor capillary circulation (Greeff, 1900; Iwanoff, 1869; Bruno, 1936; Redslob, 1952; Alaerts, 1952), arteriolar spasm (Alaerts, 1952), spasm or other vascular disorder causing nutritional trouble (Redslob, 1952). In our case we were not able to observe the least alteration of the capillaries or larger vessels.

It must be recognized that microcystoid degeneration usually has a marked predilection for two areas: the periphery, especially the temporal area (where the bilateral symmetrical cysts are nearly always found), and the posterior pole. These are the places where the retina is not only thinnest but also relatively the least vascularized, and where most of the senile and myopic degenerations are also situated.

\section{Conclusions}

(1) Cysts near the ora are usually situated on the temporal side. They 
are nearly always bilateral and symmetrical. They are mostly solitary and $\stackrel{\text { W }}{c}$ form a translucent, globular mass with a regular, smooth surface, trans-o parent contents, and clear contours. The retinal vessels are not altered at their level.

(2) Cysts without retinal detachment are not rare. We have found two cases, and Teng and Katzin have observed them in 6 per cent. of non- $\underset{\vec{\rho}}{\frac{\rho}{\sigma}}$ selected eyes.

(3) The histopathological examination of one of our cases showed that the cystic cavity was formed by the confluence of several microcysts due to $\widetilde{\varnothing}$ peripheral cystoid degeneration of the retina.

(4) The perforation of the internal and external walls, or the desinsertion $\vec{\square}$ of the retina, seems to be a necessary condition for retinal detachment.

(5) The mechanism of microcystoid degeneration is still unknown, buto. it is certainly a degenerative process, and is usually found only in patientsi. over 40 years of age.

\section{REFERENCES}

Alaerts, L. (1952). Bull. Soc. franç. Ophtal., 65, 266.

Bartels, M. (1933). Klin. Mbl. Augenheilk., 91, 437.

Bonnet, P., and Bussy, J. (1935). Bull. Soc. Ophtal., Paris, 47, 341.

Bruno, G. (1936). Arch. Augenheilk., 110, 183.

Charamis, J. S. (1947). Bull. Soc. hellénique Ophtal., 14, 23.

Custodis, E. (1936). Ber. disch. ophthal. Ges., 51, 296.

DUKE-ELDER, S. (1949). British Journal of Ophthalmology, 33, 388.

ELWYN, H. (1946). "Diseases of the Retina", p. 531. Blakiston, Philadelphia.

François, J., and Lambrechts, J. (1952). Ann. Oculist., Paris, 185, 348.

Fuchs, A. (1937). Klin. Mbl. Augenheilk., 98, 145.

GreEFF, R. (1900). In A. Graefe and T. Saemisch," Handbuch der Gesamten Augenheilkunde" 2nd ed., vol. 1, part 2, ch. 5 . Engelmann, Leipzig.

Iwanoff, A. (1869). v. Graefes Arch. Ophthal., 15, pt. 2, p. 88.

JANCKE, G. (1935). Klin. Mbl. Augenheilk., 95, 145.

KornzweIG, A. L. (1940). Arch. Ophthal., Chicago, 23, 491.

KUHNT, H. (1881). Ber. ophthal. Ges., Heidelberg, 13, 141.

KuRz, O. (1944). Ophthalmologica, Basel, 107, 233.

LANDSBERG, M. (1877). v. Graefes Arch. Ophthal., 23, pt. 1, p. 193.

LEFFERTSTRA, L. J. (1950). Ophthalmologica, Basel, 119, 1.

OCHI, S. (1927). Amer. J. Ophthal., 10, 161.

OGuch, C. (1912). v. Graefes Arch. Ophthal., 80, 537.

REDSLOB, E. (1952). Bull. Soc. franc. Ophtal., 65, 284.

RIDLEY, H. (1936). British Journal of Ophthalmology, $20,65$.

RubINo, A. (1946). Riv. Oftal., 1, 149.

SCHAUB, C. F. (1940). Amer. J. Ophthal., 23, 813.

SHAPLAND, C. DEE (1948). Trans. ophthal. Soc. U.K., 68, 115.

STALlard, H. B. (1946). British Journal of Ophthalmology, 30, 547.

Teng, C. C., and Katzin, H. M. (1953). Amer. J. Ophthal., 36, 29.

WeVE, H. (1935). Arch. Augenheilk., 109, 49. 